\title{
HUBUNGAN VERBAL ABUSE DENGAN TINGKAT KECERDASAN EMOSIONAL ANAK KELAS 5 \& 6 DI SDN 012 BALIKPAPAN KOTA
}

\author{
Vivin Sumarni $\mathrm{B}^{1}$, Siti Mukarommah ${ }^{2}$, Abdurrahman $^{3}$ \\ 1, 2, ${ }^{3}$ Program Studi IImu Keperawatan ITKES Wiyata Husada Samarinda
}

Email : vivinsumarni@gmail.com ${ }^{1}, \underline{\text { sitimukaromah@itkeswhs.ac.id }^{2}}, \underline{\text { abdurrahman@itkeswhs.ac.id }^{3}}$

\begin{abstract}
ABSTRAK
Latar Belakang Masa usia sekolah sebagai masa intelektual atau masa keserasian bersekolah. Pada usia ini anak memperoleh dasar pengetahuan dan keterampilan untuk keberhasilan penyesuaian diri anak pada kehidupan dewasanya. Tujuan penelitian ini adalah untuk menganalisis apakah ada ada Hubungan Verbal Abuse Terhadap Tingkat Kecerdasan Emosional Pada Anak kelas 5\&6 Di SDN 012 Balikpapan Kota. Metode penelitian ini merupakan penelitian kuantitatif dengan desain analitik korelasi, menggunakan pendekatan cross-sectional. Tekhnik penelitian ini menggunakan Consecutive Sampling, dan menggunakan kuisioner dalam bentuk media google form dengan jumlah responden 94 anak. Hasil penelitian dari ini dengan menggunakan uji Korelasi Product Moment menunjukkan adanya hubungan antara verbal abuse dengan tingkat kecerdasan emosional anak dengan nilai $p=0,002<\alpha \quad 0,05$. Kesimpulan diharapkan bagi peneliti selanjutnya untuk mencari banyaknya faktor lain selain verbal abuse yang dapat menyebabkan kecerdasan emosional anak terganggu.
\end{abstract}

Kata Kunci : Verbal Abuse, Tingkat Kecerdasan Emosional, Anak SD

\section{PENDAHULUAN}

Anak usia sekolah 6-12 tahun merupakan masa-masa pembentukan jati diri seorang anak. Pada masa-masa ini anak rentan bersikap keras kepala, egois, melawan dan memberontak dari peraturan-peraturan yang diberikan orang tua dengan tujuan memperoleh kebebasan serta rasa ingin tahu. Oleh karena itu banyak orang tua yang merasa anaknya sangat sulit diatur dan secara tidak sadar melakukan tindakan kekerasan kepada anaknya baik secara fisik maupun verbal. Orang tua banyak yang tidak mengetahui bahwa anak juga mempunyai hak dan kewajiban. Kekerasan pada anak meliputi berbagai macam bentuk tingkah laku dari tindakan ancaman fisik secara langsung oleh orang tua atau orang dewasa (Armiyanti, Aini, \& Apriana, 2017). Definisi anak sekolah dasar adalah mereka yang berusia antara 6-12 tahun atau biasa disebut dengan periode intelektual. Pengetahuan anak akan bertambah pesat seiring dengan bertambahnya usia, keterampilan yang dikuasaipun semakin beragam. Minat anak pada periode ini terutama berfokus pada segala sesuatu yang bersifat bergerak. Implikasinya adalah anak cenderung untuk melakukan beragam aktivitas yang akan berguna pada proses perkembangannya (Armiyanti et al., 2017). Kekerasan verbal merupakan kekerasan dalam bentuk ucapan atau kata-kata yang 
Jurnal Keperawatan Wiyata

Volume 2, Nomor 1, Tahun 2021

ISSN 2774-4558 (Cetak)

ISSN 2774-9789 (Online)

Halaman 61-70

bersifat menghina atau mempermalukan baik emosi-emiso yang akan muncul dalam anak, menolak anak, membentak, mencaci maki, dan menakuti dengan mengeluarkan kata-kata yang tidak pantas terhadap anak. Kekerasan verbal terhadap anak akan menibulkan sakit hati hingga membuat anak berfikir seperti yang kerap diucapkan oleh orang tuanya. Mengucapkan kata-kata kasar tanpa menyentuh fisik, memfitnah, mengancam, menakutkan, menghina, atau membanding-bandingkan anak dengan anak yang lain termasuk dalam golongan kekerasan verbal (Ph \& Anggraeni, 2018).

Emosi adalah kekuatan tanpa batas, energy vital yang dapat kita manfaatkan untuk meraih sukses dalam hidup. Sukses di tempat belajar, sukses di rumah, sukses dalam hubungan antar sesame dan juga sukses dalam hubungan dengan diri sendiri terletak pada kemampuan kita dalam mengendalikan emosi secara efektif. Menurut hasil penelitian yang dilakukan oleh Daniel Goelman di dalam (Gitosaroso, 2016) menggambarkan bahwa orang ber-IQ tinggi gagal, dan orang ber-IQ sedang sukses dalam hidup, hal itu dikarenakan orang tersebut memiliki kecerdasan emosional, yang mencakup pengendalian diri, semangat dan ketekunan, serta kemampuan unruk memotivasi diri sendiri. Kecerdasan emosi adalah kemampuan untuk memahami perasaan diri masing-masing dan perasaan orang lain, kemampuan untuk orang sekitarnya (Gitosaroso, 2016). World Health Organization menyatakan pada tahun 2016 di Negara adidaya Amerika Serikat yang dikenal menjunjung tinggi kebebasan dan hak asasi manusia keketasan terhadap anak adalah salah satu yang sudah umum terjadi. faktanya menunjukkan $36,7 \%$ anak mengalami serangan tanpa senjata dan sedera, 14,9\% anak mengalami serangan dengan senjata dan mengalami cedera, $6,1 \%$ mengalami kekerasan seksual, 10,2\% menjadi korban penganiayaan, $1,4 \%$ menjadi korban kekerasan verbal, 9,8\% menjadi saksi mata pada kasus kekerasan dalam rumah tangga, dan $19,2 \%$ menjadi saksi mata serangan yang terjadi di masyarakat. Menurut hasil penelitian yang dilakukan oleh (Mardia, 2018) menyebutkan data dari Official Journal of The American Academy of Pediatrics dengan judul Global Prevalence of Past-year Violence Againts Children: A Systematic Review and Minimum Estimates, 2016. Rata-rata 50\% atau diperkirakan lebih dari 1 milyar anak-anak didunia berusia 2-17 tahun, mengalami kekerasan fisik, seksual, emosional, dan penelantaran di kawasan Afrika, Asia, dan Amerika Utara mengalami kekerasan dalam satu tahun terakhir (Mardia, 2018). 
Di Indonesia, data Komnas Perlindungan Anak Indonesia (KPAI), di tahun 2006 tercatat 788 kasus kekerasan terhadap anak. Sementara informasi dari P2TP2A "Sahabat Keluarga" kota Balikpapan menyatakan bahwa ada 150 kekerasan terhadap anak di tahun 2015 dan 52 kasus hingga pertengahan tahun 2016. Komisi Perlindungan Anak Indonesia (KPAI) angka kekerasan pada anak mengalami peningkatan yang signifikan, yaitu pada tahun 2011 tercatat 2178 kasus dan pada tahun 2014 tercatat 5066 kasus (Mardia, 2018).

Hasil studi pendahuluan pada tanggal 12 juli 2020 di SDN 012 Balikpapan Kota didapatkan data jumlah anak sebanyak

178 anak terdiri dari kelas 5a 37 anak, kelas 5b 37 anak, kelas 6a 35 anak, kelas 6b 34 anak dan kelas 6c 35 anak. Didapatkan data anak yang mengalami kekerasan verbal sebanyak 20 anak. Jika memiliki kematangan emosi yang baik tidak akan ada anak yang berprilaku negatif seperti membentak kepada yang lebih tua, tidak mau mendengarkan perkataan orang tua, membantah orang tua dan hal negatif lainnya. Berdasarkan fenomena diatas banyak anak di SDN 012 Balikpapan Kota yang mengalami korban kekerasan verbal, maka peneliti tertarik untuk melakukan penelitian mengenai "Hubungan Verbal Abuse Dengan Tingkat Kecerdasan Emosional Anak kelas 5\&6 di SDN 012 Balikpapan Kota.

\section{METODE PENELITIAN}

Penelitian ini termasuk penelitian yang bersifat kuantitatif, penelitian ini menggunakan rancangan penelitian danalitik korelasi, yaitu menjelaskan hubungan antara dua variabel, yaitu variabel bebas (Verbal Abuse) dan variabel terikat (Tingkat Kecerdasan Emosional di SDN 012 Balikpapan Kota (Nursalam, 2016). Dengan metode pendekatan cross sectional, yaitu suatu pendekatan penelitian dimana variabel- variabel yang termasuk diobservasi sekaligus pada waktu yang sama.

\section{HASIL PENELITIAN}

Tabel 1 Distribusi data demografi berdasarkan kelas dan jenis kelamin di SDN 012 Balikpapan Kota $(n=94)$

\begin{tabular}{lll}
\hline Karakteristik & $\mathbf{F}$ & $\%$ \\
\hline Kelas : & & \\
& & \\
$5 \mathrm{~A}$ & 9 & $9,7 \%$ \\
5B & 43 & $45,7 \%$ \\
$6 \mathrm{~A}$ & 8 & $8,6 \%$ \\
$6 \mathrm{~B}$ & 26 & $28,0 \%$ \\
$6 \mathrm{C}$ & 8 & $8,6 \%$ \\
\hline TOTAL & 94 & $100 \%$ \\
\hline Jenis Kelamin : & & \\
Laki- laki & 47 & $50 \%$ \\
Perempuan & 47 & $50 \%$ \\
\hline TOTAL & 94 & $100 \%$ \\
\hline
\end{tabular}


Tabel 2 Analisis univariat variabel verbal abuse dengan kecerdasan emosional $(n=94)$

\begin{tabular}{llll}
\hline No & Variabel & $\mathrm{F}$ & presentase \\
\hline 1 & Verbal & & \\
& abuse & & \\
& Ringan & 47 & $50,0 \%$ \\
& Berat & 47 & $50,0 \%$ \\
\hline 2 & Kecerdasan & & \\
& emosional & & \\
& Baik & 35 & $37,2 \%$ \\
& Tidak Baik & 59 & $62,8 \%$ \\
& Total & 188 & $100 \%$ \\
\hline
\end{tabular}

Tabel 3. Hasil Analisis Hubungan Verbal Abuse Dengan Tingkat Kecerdasan Emosional Anak Kelas 5 \& 6 Di SDN 012 Balikpapan Kota

\begin{tabular}{llcc}
\hline corelation & \multicolumn{1}{c}{$\begin{array}{c}\text { Verbal } \\
\text { abuse }\end{array}$} & $\begin{array}{c}\text { Kecerdasan } \\
\text { emosional }\end{array}$ \\
\hline $\begin{array}{l}\text { Verbal } \\
\text { abuse }\end{array}$ & $\begin{array}{l}\text { Pearson } \\
\text { Corelation } \\
\text { Sig }(2-\end{array}$ & 1 & .314 \\
& $\begin{array}{l}\text { tailed }) \\
\text { Kecerdasan }\end{array}$ & $\mathrm{N}$ & .002 \\
\hline Emosional & Correlation & .314 & 1 \\
\hline & $\begin{array}{l}\text { Sig } \\
\text { tailed })\end{array}$ & .002 & \\
\hline & $\mathrm{N}$ & 94 & 94 \\
\hline
\end{tabular}

\section{PEMBAHASAN}

\section{Verbal abuse}

Hasil sebaran data pada verbal abuse pada anak kelas $5 \& 6 \mathrm{di}$ SDN 012 Balikpapan Kota memiliki nilai rata- rata 22,2128 dan nilai tengah 21,5000

nilai rentang min-max $15-41$, dapat diartikan dari total responden $\mathrm{n}$ (94) didapatkan nilai min-max verbal abuse dengan rentang skor 15-41 nilai ratarata 22,2128 dan nilai tengah 21,5000 .

Data penelitian jumlah 94 orang didapatkan hasil ukur verbal abuse ringan sebanyak 47 orang dengan presentase $(50 \%)$, dan hasil ukur berat sebanyak 47 orang dengan presentase (50\%). Diketahui bahwa anak yang mengalami verbal abuse kategori ringan dengan kecerdasan emosional baik sejumlah 15 orang anak $(31,9 \%)$, atau anak yang mengalami verbal abuse kategori berat dengan tingkat kecerdasan emosional baik sejumlah 20 orang $(42,6 \%)$, ini terjadi karena adanya perlakuan orang tua terhadap anak usia sekolah secara langsung mempengaruhi tingkat kecerdasan emosional anak yang tertanam sejak kecil.

Kekerasan verbal menurut Suharto (2010) didalam (Nugroho, 2016) kekerasan verbal merupakan tindakan yang meliputi penghardikan dan penyampaian kata-kata kasar. Sejalan dengan itu Lawson (2010) didalam (Nugroho, 2016) juga mengatakan kekerasan verbal adalah tindakan yang berupa penghinaan, pelecehan, dan memberi label seseorang dalam 
suatu pola komunikasi. Menurut Surbakti (2012) didalam (Vega, Hapidin, \& Karnadi, 2019) kekerasan terbagi atas dua bagian yaitu kekerasan fisik dan verbal abuse. Tidak banyak orang tahu bahwa kekerasan yang dilakukan secara verbal atau kata-kata ternyata memilki efek yang lebih dahsyat dibandingkan dengan kekerasan fisik. Didukung dalam penelitian Armayanti (2017) didalam (Vega et al., 2019) yang mengkaji bahwa kekerasan verbal sering kali dilakukan oleh orang tua.

Orang tua yang tidak melakukan verbal abuse atau tindakan kasar dan selalu merespon setiap kegiatan anak dapat berpengaruh terhadap tingkat kecerdasan emosional anak. Begitupun orang tua yang melakukan kekerasan verbal akan berpengaruh besar terhadap tingkar kecerdasan emosi anak. Dengan latar belakang mungkin kurangnya informasi mengenai verbal abuse memungkinkan bahwa pengetahuan orang tua tentang tingkat kecerdasan emosional anak juga kurang yang mana hal tersebut dapat berpengaruh pada perilaku/ cara orang tua dalam melakukan verbal abuse pada anak yang dapat menyebabkan tingkat kecerdasan anak yang berbeda- beda

Adapun hasil yang menunjukkan anak dengan verbal abuse kategori emosional tidak baik sejumlah 32 orang $(68,1 \%)$ ataupun anak dengan verbal abuse kategori berat dengan kecerdasan emosional tidak baik sejumlah 27 anak $(57,4 \%)$, hal ini disebabkan tingkat kecerdasan emosional tidak hanya dipengaruhi oleh kejadian verbal abuse orang tua tetapi juga dipengaruhi oleh faktor lainnya yaitu Lingkungan keluarga dan non keluarga. Lingkungan keluarga antara lain peran serta orang tua karena orang tua adalah subjek pertama yang akan di tiru oleh anaknya yang akan menjadi bagian dari kepribadian anak. Sedangkan non keluarga seperti lingkungan yang ada di masyarakat dan lingkungan penduduk. Apabila faktor lain ini lebih dominan mempengaruhi perilaku tentu saja dapat mengakibatkan kejadia verbal abuse tidak lagi mempengaruhi tingkat kecerdasan emosional anak.

\section{Kecerdasan emosional}

Hasil sebaran data pada kecerdasan emosional pada anak kelas $5 \& 6$ di SDN 012 Balikpapan Kota memiliki nilai rata-rata 87,5213 dan nilai tengah 88,000 nilai rentang min-max 79-96, dapat diartikan dari total responden $n$ (94) didapatkan nilai min-max kecerdasan emosional dengan rentang skor min-max 79-96 
Jurnal Keperawatan Wiyata

Volume 2, Nomor 1, Tahun 2021

ISSN 2774-4558 (Cetak)

ISSN 2774-9789 (Online)

nilai rata-rata 87,5213 dan nilai tengah 88,000 .

Data penelitian jumlah responden 94 orang di dapatkan hasil ukur kecerdasan emosional baik sebanyak

35 responden dengan presentase $(37,2 \%)$, dan hasil ukur kecerdasan emosional tidak baik sebanyak 59 responden dengan presentase (62,8\%). Hal tersebut menunjukkan bahwa murid kelas 5 \& 6 SDN 012 memiliki tingkat kecerdasan emosional yang tidak baik karena tidak mampu melaksanakan tugas perkembangan emosinya. Penelitian ini sejalan dengan penelitian (Ummah, 2017) menyatakan bahwa siswa madrasah ibtidaiyah Sunan Kalijogo 1 Tinggar kelas III,IV,V dengan tingkat kecerdasan emosional sedang sebanyak 7 siswa dari 46 siswa, artinya sebagian kecil subjek penelitian ini dalam kategori kecerdasan emosional yang kurang stabil.

Kecerdasan emosional sangat berpengaruh dalam kehidupan sosial, karena dalam kehidupan sosial terdapat interaksi yang terjadi dalam lingkungan masyarakat atau sosial. Kecerdasan emosional adalah suatu kesatuan kecerdasan dibidang sosial yang melibatkan keadaan emosional untuk memantau perasaan dan emosi pada diri sendiri dengan mengontrol

perilaku mana yang pantas dan yang tidak pantas ditunjukkan pada lingkungan di dalam dan di luar lingkungan. Kecerdasan emosional merupakan suatu kemampuan yang dimiliki seseorang dalam hal berkaitan dengan emosinya. Kecerdasan emosional seseorang dapat dilihat dari rasa empatinya terhadap orang lain atau lingkungan sekitarnya, kecerdasan emosional juga dapat dilihat dari mengungkapkan dan memahami perasaan, kemudian kecerdasan emosional dilihat dari kemampuan menyesuaikan diri, kecerdasan emosional lainnya juga dilihat dari ketekunan anak dalam melakukan sesuatu, adapula kecerdasan emosional dilihat dari sikap yang ramah dan sikap sopan anak (Anggraini \& Oliver, 2019).

Anak dengan tingkat kecerdasan emosional yang tidak baik cenderung melakukan tindakan yang dapat merugikan diri dan lingkungannya seperti membangkang, berbicara kasar, sehingga tingkah laku yang kurang berkenan kerap sekali muncul pada anak yang memiliki kecerdasan emosional yang tidak baik. Sikap orang tua terhadap anak seharusnya sudah tidak memandang tingkah laku anak yang kurang baik melainkan orang tua memandang semua perilaku anak merupakan sebagian 
dari proses perkembangan dan pertumbuhan sikap menuju kearah yang lebih baik.

3. Hubungan verbal abuse dengan tingkat kecerdasan emosional

Hasil penelitian analisis univariat pada verbal abuse menunjukkan bahwa dari 94 responden didapatkan

$47 \quad(50,0 \%) \quad$ responden mengalami verbal abuse ringan, $47 \quad(50,0 \%) \quad$ responden mengalami verbal abuse berat. Hasil tersebut menunjukkan bahwa anak yang mengalami verbal abuse memiliki persamaan. Pada hasil analisis bivariat menunjukkan hubungan antara verbal abuse dengan tingkat kecerdasan emosional anak dengan menggunakan uji Korelasi Product Moment diperoleh bahwa nilai $p=0,002<$ a 0,05 menandakan bahwa ada hubungan verbal abuse dengan tingkat kecerdasan emosional anak.

Dari hasil penelitian sejalan dengan yang dilakukan oleh (Agustin, 2018) mengatakan bahwa verbal abuse berhubungan dengan tingkat kecerdasan emosional anak. Hasil dari penelitian yang didapatkan bahwa sebagian besar dari responden mengalami kekerasan verbal sedang sebanyak 18 responden $(56,2 \%)$ dan hampir seluruhnya anak memiliki tingkat emosional cukup banyak yaitu

27 responden $(84,4 \%)$, nilai $\rho=0,02<$ 0,05 .

Penelitian ini juga sejalan dengan penelitian (Mamesah \& Katuuk, 2018) yang mengatakan bahwa terdapat hubungan yang signifikan antara verbal abuse dengan perkembangan kognitif anak pada usia sekolah di SD Inpres Tempok. Hasil dari penelitian didapatkan bahwa sebagian besar anak mendapatkan verbal abuse ringan dari orang tuanya $(76,7 \%)$, dan sebagian besar anak memiliki perkembangan kognitif sesuai $(56,7 \%)$ dan dimana $P$ value $>0,05$ adalah $P=0,025$.

Dari penjelasan diatas di jelaskan bahwa masih banyak anak-anak yang mengalami verbal abuse dan mendapatkan dampak yang negatif pada kecerdasan emosionalnya yang memungkinkan bahwa anak yang telah mendapatkan verbal abuse dari orang tuanya mengalami tidak mampu mengenali emosinya, mengelola emosinya pada saat mengalami ancaman atau sedang dimarahi, tidak dapat memotivasi dirinya, dan ditakutkan anak tidak dapat membina hubungan dengan orang lain dengan keluarga atau dengan teman sebayanya.

Menurut peneliti sendiri dengan tidak dilakukannya verbal abuse kepada anak maka anak akan dapat 
mengelola kecerdasan emosi

diri sendiri. Kemudian diharapkan dengan tidak adanya verbal abuse kepada anak, anak dapat mampu untuk mengontrol emosinya, mengendalikan emosi, memotivasi dirinya, dan menjalin hubungan dengan orang lain. Jika verbal abuse selalu dilakukan oleh orang tua ditakutkan anak tidak dapat mengelola emosional pada diri sendiri dan menjadi anak pembangkang, kurang bersosialisasi kepada orang lain, dan melakukan tingkah laku yang kurang sopan yang ditunjukkan oleh anak.

\section{KESIMPULAN}

Hasil penelitian Hubungan Verbal Abuse Dengan Tingkat Kecerdasan Emosional Anak Kelas 5 \& 6 Di SDN 012 Balikpapan Kota : Hasil analisia bivariat dengan menggunakan uji Korelasi Product Moment diperoleh hasil yang menunjukkan bahwa terdapat hubungan verbal abuse dengan tingkat kecerdasan emosional anak, dengan nilai $\mathrm{P}$ Value yang didapatkan 0,002 yang lebih kecil dari nilai $\mathrm{n}=0,05$. Maka Ha diterima dan Ho ditolak, yang berarti ada hubungan antara verbal abuse dengan tingkat kecerdasan emosional.

\section{DAFTAR PUSTAKA}

Agustin, nirwana dewi. (2018). Hubungan kekerasan verbal orang tua dengan perkembangan kognitif anak.
Aliyah, M., \& Man, N. (2018). Dengan Komunikasi Interpersonal Pada Siswa Oleh: Fikriyah Iftinan Fauzi Program Studi Magister Psikologi Program Pascasarjana Universitas Medan Area Medan Madrasah Aliyah Negeri ( Man ) Binjai TESIS Diajukan sebagai salah satu syarat untuk memperoleh gel.

Ananta, M. J. (2016). Pengaruh Kecerdasan Emosional Terhadap Prestasi Belajar Pada Siswa Kelas V SDN Ketawanggede Malang. 41. Retrieved from etheses.uinmalang.ac.id/2771/1/10410137.pdf\% $0 \mathrm{~A} \% 0 \mathrm{~A}$

Anggraini, A. R., \& Oliver, J. (2019). Dampak Kekerasan Orang Tua Terhadap Perkembangan Kecerdasan Emosional Anak Usia Dini Di Desa Pajar Bulan Kabupaten Kaur, 53(9), 1689-1699.

https://doi.org/10.1017/CBO9781107 415324.004

Armiyanti, I., Aini, K., \& Apriana, R. (2017). Pengalaman Verbal Abuse Oleh Keluarga Pada Anak Usia Sekolah Di Kota Semarang. Jurnal Keperawatan Soedirman, 12(1), 12. https://doi.org/10.20884/1.jks.2017.12 .1 .714

Freeman. (2016). PERSEPSI ORANG TUA TENTANG KEKERASAN VERBAL PADA ANAK DI KECAMATAN SEKAMPUNG UDIK LAMPUNG TIMUR, 53(9), 16891699.

https://doi.org/10.1017/CBO9781107 415324.004 
Gitosaroso, M. (2012). Kecerdasan Emosi

( Emotional Intelligence) dalam

Tasawuf. Jurnal Khatulistiwa, 2(2), 182-200.

goleman, daniel; boyatzis, Richard;

Mckee, A. (2019). Journal of Chemical Information and Modeling, 53(9), 1689-1699.

https://doi.org/10.1017/CBO9781107 415324.004

Latifah, „Ainiyatul. (2018). Kecerdasan Santri Tunanetra dalam Menghafal Al-Qur"an. Skripsi, 15-57.

Mamesah, A., \& Katuuk, M. (2018). Hubungan Verbal Abuse Orang Tua Dengan Perkembangan Kognitif Pada Anak Usia Sekolah. Journal Keperawatan, 6(November), 1-6.

Mardia, R. (2018). infoDATIN (pusat data informasi kementrian kesehatan RI kekerasan terhadap anak dan remaja (p. 11). p. 11.

Retrieved from

https://www.depkes.go.id/resources $/ d$

ownload/pusdatin/infodatin/Kekeras a n-terhadap-anak.pdf

Nugroho, M. B. (2016). HUBUNGAN ANTARA KEKERASAN VERBAL YANG DIALAMI ANAK DENGAN KEPERCAYAAN DIRI REMAJA, 53(9), 16891699.

https://doi.org/10.1017/CBO97811 07415324.004

Ph, L., \& Anggraeni, R. (2018). Fisik dan Verbal pada Anak Usia Sekolah di Kota Kendal. Jurnal Ners Dan Kebidanan, Volume 5(No. 2), 97-
104.

https://doi.org/10.26699/jnk.v5i2.ART. p097

Putri, R. P., Dewi, R., Sari, P., \& Ayu, P.

R. (2019). Perbandingan Faktor-

Faktor yang Mempengaruhi

Penggunaan Kontrasepsi Intra

Uterine Devices ( IUD ) dan

Kontrasepsi Implant pada Wanita

Usia Subur di Kecamatan Sukarame

Kota Bandarlampung. Majority, 8(2), 120-124.

Ririn Wesliner. (2016). HUBUNGAN

ANTARA MINAT DAN PRESTASI BELAJAR SEJARAH DENGAN KESADARAN SEJARAH SISWA

MAN YOGYAKARTA III.

Semarang, U. K. (2015). Hubungan Verbal Abuse Dengan Perkembangan Emosi Anak Usia Sekolah Kelas 3-5 di SD N Genuk 01 Ungaran Kabupaten Semarang 1. 28, 1-9.

Sudrajat, A. (2017). Persepsi Minat Belajar Siswa Pada Mata Pelajaran Pengantar Akuntansi Keuangan Rumpun Lintas Minat SMK N 3 Bandung.

Susilana, R. (2015). Modul Populasi dan Sampel. Modul Praktikum, 3-4. Retrieved from

http://file.upi.edu/Direktori/DUALMODES/PENELITIAN_PENDIDIKAN/ BBM_6.pdf

Ummah, ummi latifatul. (2017). Sugiyono. (2017). Metode Penelitian Pendidikan Pendekatan Kuantitatif, Kualitatif dan R\&D. Bandung: Alfabeta. Hubungan Intensitas Komunikasi Dan Kelekatan Orang Tua-Anak Dengan Kecerdasan Emosional Siswa Madrasah Ibtidaiyah 
Sunan Kalojogo 1 Tinggar, Bandar

Kedungmulyo, Jombang, (3),

43.

https://doi.org/10.1017/CBO9781107

415324.004

Utami, M. (2016). Hubungan Aspek

Spiritual dan Kualitas Hidup pada

Pasien Kanker dengan Kemoterapi.

Vega, A. De, Hapidin, H., \& Karnadi, K. (2019). Pengaruh Pola Asuh dan Kekerasan Verbal terhadap Kepercayaan Diri (Self-Confidence). Jurnal Obsesi: Jurnal Pendidikan

Anak Usia Dini, 3(2), 433. https://doi.org/10.31004/obsesi.v3i2.2 27

Wijaya, B. A. (2016). Hubungan

Kecerdasan Emosional Dengan

Sikap Terhadap Bullying Pada Anak

Usia Sekolah Di Sd Negeri

Gambiranom Condong Catur Depok

Sleman Yogyakarta. Unisa, 1-14.

Wijayanti, V. D. (2017). Hubungan

Verbal Abuse Terhadap

Perkembangan Kognitif Anak Usia

Pra Sekolah Di kelurahan Reban

Kabupaten Batang. Doctoral

Dissertation Faculty of Medic. 